\title{
Protocolos de resguardo del Patrimonio Cultural por riesgo climático
}

\author{
N. Bortolin y L. Solazzi \\ Museo Naval de la Nación. Av. Victorica 602, B1648 Tigre, Pcia de Buenos Aires. \\ https://museonavaldelanacion.wordpress.com/
}

Dado que los efectos del Cambio Climáticos ya están afectando a personas, a bienes, a servicios, y a los atractivos culturales de los destinos turísticos, es necesario superar el estadio del mero discurso de la sostenibilidad y pasar a los hechos concretos de gestión tanto para mitigar o reducir la producción los gases de efecto invernadero, como así también prepararse y adaptarse a las amenazas climáticas. Cuanto más preparadas se encuentren las sociedades (ser más sustentables), serán menos vulnerables a los efectos del Cambio Climático. Por tanto, Cambio Climático es una oportunidad para el desarrollo sostenible del turismo preservando y protegiendo el patrimonio cultural como los museos. Desde el marco teórico practico de la "conservación preventiva" en el presente trabajo se describen los lineamientos generales de acción frente a las distintas amenazas climática 0 antrópicas que afectan al patrimonio cultural tangible. En particular se describen los procesos y agentes de deterioro, y los procesos de conservación de los bienes culturales, como así también el rol que le cabe al restaurador en tales procesos. De este último se describen sus objetivos, ideología, alcances y métodos de trabajo.

Palabras claves: patrimonio cultural, conservación preventiva, procesos, deterioro, restaurador 